\title{
Yamada
}

Fifty-Fifth International Symposium on "Biological Regulation and Enzyme Activity in Normal and Neoplastic Tissues" September 15-16, 2014, University of Bologna, Italy Aemilia Hotel Conference Centre, Via Zaccherini Alvisi

\section{Role of $\mathrm{IP}_{3}$ receptor signaling in cell functions and diseases}

\author{
Katsuhiko Mikoshiba \\ Laboratory for Developmental Neurobiology, RIKEN Brain Science Institute, \\ 2-1 Hirosawa, Wako-shi, Saitama, Japan
}

\begin{abstract}
IP}_{3}$ receptor $\left(\mathrm{IP}_{3} \mathrm{R}\right)$ was found to release $\mathrm{Ca}^{2+}$ from non-mitochondrial store but the exact localization and the mode of action of $\mathrm{IP}_{3}$ remained a mystery. $\mathrm{IP}_{3} \mathrm{R}$ was identified to be $\mathrm{P}_{400}$ protein, a protein, which was missing in the cerebellum of ataxic mutant mice lacking $\mathrm{Ca}^{2+}$ spikes in Pukinje cells. $\mathrm{IP}_{3} \mathrm{R}$ was an $\mathrm{IP}_{3}$ binding protein and was a $\mathrm{Ca}^{2+}$ channel localized on the endoplasmic reticulum. Full-length cDNA of $\mathrm{IP}_{3} \mathrm{R}$ type 1 was initially cloned and later two other isoforms of $\mathrm{IP}_{3} \mathrm{R}$ (IP3R type 2 and type 3 ) were cloned in vertebrates. Interestingly, the phosphorylation sites, splicing sites, associated molecules, $\mathrm{IP}_{3}$ binding affinity and 5 ' promoter sequences of each isoform were different. Thus each isoform of $\mathrm{IP}_{3}$ receptor plays a role as a signaling hub offering a unique platform for matching various functional molecules that determines different trajectories of cell signaling. Because of this distinct role of each isoform of $\mathrm{IP}_{3} \mathrm{R}$, the dysregulation of $\mathrm{IP}_{3}$ receptor causes various kinds of diseases in human and rodents such as ataxia, vulnerability to neuronal degeneration, heart disease, exocrine secretion deficit, taste perception deficit. Moreover, $\mathrm{IP}_{3}$ was found not only to release $\mathrm{Ca}^{2+}$, but also to release IRBIT ( $\underline{I P}_{3}$ receptor binding protein released with inositol trisphosphate) essential for the regulation of acid-base balance, RNA synthesis and ribonucleotide reductase.
\end{abstract}

The beginnings When cells receive signals through receptors on the plasma membrane, the information is transmitted to various types of signaling cascades inside the cells leading cells to respond. Among the various intracellular signaling pathways, $\mathrm{IP}_{3}$ signaling and diacylglycerol (DAG)-protein kinase C (PKC) pathways are fundamental to cell physiology. Upon activation of 
upstream receptors, two messenger molecules, $\mathrm{IP}_{3}$ and $\mathrm{DAG}$ are hydrolysed from phosphatidylinositol 4,5-bisphosphate (PIP2). This bifurcating signaling pathway is of fundamental importance in regulating a wide range of cellular processes (Fig. 1). DAG activates PKC to phosphorylate various proteins, leading to various cellular responses. As for the other messenger molecule $\mathrm{IP}_{3}$, an important breakthrough occurred when it was demonstrated that $\mathrm{IP}_{3}$ releases $\mathrm{Ca}^{2+}$ from non-mitochondrial internal stores (Streb et al. 1983) and that this $\mathrm{Ca}^{2+}$ released from internal store seemed to play various roles. It was puzzling why $\mathrm{IP}_{3}$, a molecule with such simple structure, could exert such diverse functions.

\section{Search for the target molecule of $\mathrm{IP}_{3}$}

Why does $\mathrm{IP}_{3}$ exert such a variety of phenomena? The source of variety could be the function of $\mathrm{Ca}^{2+}$ or $\mathrm{IP}_{3} \mathrm{R}$. There are many papers on the function of $\mathrm{Ca}^{2+}$ up to now (Carafoli and Klee 1999; Mikoshiba 2007b; Mikoshiba 2012; Pochet 2000; Signal 1995) (Islam 2012). Therefore, I here focus on the mechanism how $\mathrm{IP}_{3}$ signal is converted to multiple signals. To understand the function of $\mathrm{IP}_{3}$, one way is to analyze the enzymes that synthesizes or degrade $\mathrm{IP}_{3}$. Another way is to study the property of the target molecule of $\mathrm{IP}_{3}, \mathrm{IP}_{3}$ receptor, and investigate its biochemical, molecular and physiological properties. For this purpose they tried to identify $\operatorname{IP}_{3} \mathrm{R}$ protein. There were various approaches to understand the property of $\mathrm{IP}_{3} \mathrm{R}$. One approach is to purify $\mathrm{IP}_{3}$ binding protein and to subsequently determine of the amino acid sequence. Another approach is to clone the cDNA that encodes the full-length $\mathrm{IP}_{3} \mathrm{R}$, which also tells us the amino acid sequence of the $I_{3} R$. The most important thing was to purify and characterize the $I_{3} R$ from the aspects of biochemistry and physiology.

\section{Purification of the $\mathrm{IP}_{\mathbf{3}}$ receptor $\quad$ Many}

researchers were attempting to purify the protein from various tissues (Spat et al. 1986) (Prentki et al. 1984; Sudhof et al. 1991; Supattapone et al. 1988) (Maeda et al. 1988): The $\mathrm{IP}_{3}$ binding protein was purified from rat cerebellum (Supattapone et al. 1988) (Maeda et al. 1988), bovine cerebellum (Hingorani and Agnew 1991; Hingorani and Agnew 1992), bovine aorta smooth muscle (Chadwick, Saito and Fleischer 1990), rat vas deferens (Mourey et al. 1990) and Xenopus laevis oocytes (Parys et al. 1992).

\section{cDNA cloning of the $\mathrm{IP}_{3} \mathrm{R}$}


One approach was to screen the cDNA expression library by the antibodies which were specific to the $\mathrm{IP}_{3}$ receptor. Surprisingly, most successful approach to identify $\mathrm{IP}_{3} \mathrm{R}$ protein and raising antibody against it was the analysis of the ataxic mutant cerebellum. During the analysis of the cerebellar ataxic mutant, $\mathrm{P}_{400}$ protein, high molecular glyco-phospho-membrane protein was found to be almost missing in the cerebellum of mutant mice such as pcd (Purkinje cell degeneration), which lacks the cerebellar Purkinje neurons, or staggerer whose dendritic arborization is poor and whose spines on the dendrites were completely absent (Maeda et al. 1989; Maeda et al. 1988; Mikoshiba, Huchet and Changeux 1979). Later it was also found that staggerer mutant lacked $\mathrm{Ca}^{2+}$ spikes in the Purkinje cells in the cerebellum (Crepel, Dupont and Gardette 1984). As long as two years and a half were spent raising the specific monoclonal antibodies against $\mathrm{P}_{400}$. Finally $\mathrm{P}_{400}$ was identified to be the $\mathrm{IP}_{3} \mathrm{R}$. One important piece of evidence to conclude that $\mathrm{P}_{400}$ was indeed $\mathrm{IP}_{3}$ receptor was the fact that $\mathrm{P}_{400}$ monoclonal antibody immunoprecipitated the $\mathrm{IP}_{3}$ binding activity from the solubilized cerebellar tissues. Expression cloning from the cDNA library of the cerebellum using the specific monoclonal antibodies successfully led them to clone the entire sequence of $\mathrm{IP}_{3} \mathrm{R}$ type $1\left(\mathrm{IP}_{3} \mathrm{R} 1\right)$. The sequence was about 10 kilo base-pair and encoding a peptide of about 2700 amino acids long. (Furuichi, Yoshikawa and Mikoshiba 1989) (Furuichi et al. 1989) Another group used a different approach using differential subtraction analysis of cerebellar cDNAs between wild-type and the $p c d$ (Purkinje cell deficient) mutant. The partial sequence (PCD6) obtained by differential subtraction (Nordquist, Kozak and Orr 1988) was found to be different from that of the ryanodine receptor reported by Prof. Numa (Takeshima et al. 1989). The partial sequence was hypothesized to be part of the sequence of the putative $\mathrm{IP}_{3}$ receptor judged from the sequence homology and its localization at ER (Mignery et al. 1989).

cDNA cloning of $\mathrm{IP}_{3} \mathrm{R}$ from various species was successful. There are three isoforms in vertebrates (Furuichi et al. 1994; Mikoshiba 2007a): human (Yamada et al. 1994; Yamamoto-Hino et al. 1994), mouse (Furuichi, Yoshikawa and Mikoshiba 1989; Furuichi et al. 1989; Iwai et al. 2005; Yamada et al. 1994), rat (Mignery et al. 1990) (Südhof et al. 1991), Xenopus laevis (Kume et al. 1993) and single isoform in invertebrates (star fish)(Iwasaki et al. 2002), C. elegance (Dal Santo et al. 1999), Drosophila melanogaster (Hasan and Rosbash 1992; Yoshikawa et al. 1992), Trypanosoma Cruzi (Hashimoto et al. 2013) are found.

\section{$\mathrm{IP}_{3} \mathrm{R}$ works as a signaling hub for diversified cell function}


There are accumulating evidences that $\mathrm{IP}_{3}$ receptor plays an important role in cell function. Importance of the fact that $\mathrm{IP}_{3} \mathrm{R}$ forms macro-molecular complex which works as a signaling hub by association with various molecules and determines its direction of cell signaling pathways is now recognized, which makes it possible for $\mathrm{IP}_{3} \mathrm{Rs}$ to produce diversified cell signaling by using simple $\mathrm{IP}_{3}$ molecule.

\section{1) Unique biochemical and biophysical property of the $\operatorname{IP}_{3} R$}

$\mathrm{IP}_{3}$ receptor is a large protein with molecular weight 313,000 dalton. $313 \mathrm{kilo}$ Dalton protein is a monomer and $\mathrm{IP}_{3}$ receptor was found to be composed of tetramer (Maeda et al. 1991). Intensive biochemical and biophysical studies were performed by many researchers and it was found that $\mathrm{IP}_{3} \mathrm{R}$ has $\mathrm{IP}_{3}$ binding site located at the $\mathrm{N}$-terminal portion and transmembrane region existed at the C-terminal portion (Foskett et al. 2007; Mikoshiba 2007a) (Patterson, Boehning and Snyder 2004)

It was not clearly demonstrated that $\mathrm{IP}_{3} \mathrm{R}$ is a $\mathrm{Ca}^{2+}$ channel, since all the data was obtained by using the microsomal fraction which contained endoplasmic reticulum, plasma membrane and other membrane fractions (Bezprozvanny, Watras and Ehrlich 1991). However Purified tetrameric $\mathrm{IP}_{3} \mathrm{R}$ was found to be a $\mathrm{Ca}^{2+}$ channel in the presence of $\mathrm{IP}_{3}$ and $\mathrm{Ca}^{2+}$ by incorporating a purified $\mathrm{IP}_{3}$ binding protein into lipid bilayer and liposome (Ferris, Huganir and Snyder 1990; Foskett et al. 2007; Maeda et al. 1991; Mikoshiba 2007a). The overexpression of $\mathrm{IP}_{3}$ receptor type 1 cDNA enhanced $\mathrm{IP}_{3}$ binding activity and $\mathrm{Ca}^{2+}$ release activity (Miyawaki et al. 1990). Immunohistochemical study showed that it is localized on the endoplasmic reticulum (Otsu et al. 1990) (Satoh et al. 1990; Yamamoto et al. 1991)

At the $\mathrm{N}$-terminal domain of $\mathrm{IP}_{3}$ binding pocket, there is a unique sequence called suppressor domain which is important for 1) isoform specific suppressing activity for the $\mathrm{IP}_{3}$ binding activity that produces an isoform specific $\mathrm{IP}_{3}$ binding affinity and for 2) gating the channel pore of the $I_{3} R$. IP $\quad P_{3} R$ forms tetramer and $I_{3} R$ was found to work as an allosteric protein by modulating its structure by $\mathrm{Ca}^{2+}, \mathrm{IP}_{3}$, ATP and other modulator proteins. Whole tetrameric $\mathrm{IP}_{3} \mathrm{R}$ changes its conformation dynamically observed by electron microscopy (Hamada et al. 2002) (Hamada 
and Mikoshiba 2012; Hamada, Terauchi and Mikoshiba 2003) and FRET analysis (Shinohara et al. 2011).

$\mathrm{IP}_{3}$ receptors form heterotetramer by cross-linking experiment (Monkawa et al. 1995) as well as homotetramer. The size of each isoform of $\mathrm{IP}_{3} \mathrm{R}$ seems to be homologous as far as the localization of $\mathrm{IP}_{3}$ binding site at $\mathrm{N}$-terminal side, channel region at the $\mathrm{C}$-terminal side. But when compared in detail, there are various differences among three isoforms.

Firstly, 5' promoter region of $\mathrm{IP}_{3}$ receptors are different, and secondly, $\mathrm{IP}_{3}$ binding affinity of each isoform is different among three isoforms. The thirdly, glycosylation and the phosphorylation site, splicing site is different among the three isoforms.

The difference of 5' promoter sequence of each isoform suggests that each $\mathrm{IP}_{3} \mathrm{R}$ isoform are expressed specifically in each type of cells informing us isoform-specific cell expression.

$\mathrm{IP}_{3}$ binding affinity of $\mathrm{IP}_{3}$ binding pocket from each isoform was almost the same, suggesting that other region determines $\mathrm{IP}_{3}$ binding affinity (Iwai et al. 2007). The specific $\mathrm{IP}_{3}$ binding affinity was found to be regulated by the suppressing activity by $\mathrm{N}$-terminal region, therefore this region was called suppressor domain (SD) (Yoshikawa et al. 1999a).

(Yoshikawa et al. 1999b) (Uchida et al. 2003)

The glycosylation sites and phosphorylation sites may play a role for unique functions of each isoform and the function should be studied furthermore. These differences in the posttranscriptional modification suggest that each isoform of $\mathrm{IP}_{3} \mathrm{R}$ binds to many different functional proteins.

\section{2) $I P_{3} R$ associates with various molecules}

Actually $\mathrm{IP}_{3} \mathrm{R}$ was found to bind various types of molecules. $\mathrm{IP}_{3} \mathrm{R}$ binds glutamate receptor (mGluR, AMPA receptor, NMDA receptor) through cytoskeletal proteins. Cytoskeletal protein, homer binds to the $\mathrm{N}$-terminal part and $4.1 \mathrm{~N}$ binds to $\mathrm{C}$-terminal part of $\mathrm{IP}_{3} \mathrm{R} 1$. GRP78, a typical ER chaperone binds specifically to the third luminal loop of $\mathrm{IP}_{3} \mathrm{R} 1$ and interacts and work together to resist to ER-stress. Association of GRP78 to $\mathrm{IP}_{3} \mathrm{R} 1$ is decreased by the ER-stress and also in the cells of Huntington disease mouse and also the cells from the patients (Higo et al. 2010). ERp44 is a homologue of thioredoxin family and interacts under reduced condition with the third lumenal loop of $\mathrm{IP}_{3} \mathrm{R} 1$ and inhibits $\mathrm{IP}_{3}$ induced $\mathrm{Ca}^{2+}$ release (Higo et al. 2005). GIT1 and GIT2 are G-protein-coupled Receptor Kinase-interacting Proteins and associate with the C-terminal tail of all $\mathrm{IP}_{3} \mathrm{R}$ isoforms in a $\mathrm{Ca}^{2+}$ dependent manner inhibit $\mathrm{IP}_{3} \mathrm{R}$ (Zhang et al. 2009). 
$80 \mathrm{~K}-\mathrm{H}$ interacts with the C-terminal tail of all $\mathrm{IP}_{3} \mathrm{Rs}$ and stimulate $\mathrm{IP}_{3} \mathrm{R}$ (Kawaai et al. 2009). Cytochrome $c$ interacts with the $\mathrm{C}$-terminal tail of $\mathrm{IP}_{3} \mathrm{R} 1$ and 3 and suppresses $\mathrm{IP}_{3} \mathrm{R}$ inhibition by high cytosolic $\mathrm{Ca}^{2+}$ (Boehning et al. 2003). Huntingtin which is considered to be a causal gene interacts with the $\mathrm{C}$-terminal tail of $\mathrm{IP}_{3} \mathrm{R} 1$ and sensitize the $\mathrm{IP}_{3} \mathrm{R}$ to $\mathrm{IP}_{3}$ depending on the polyQ extension and the presence of Huntingtin-associated protein 1 (Tang et al. 2003). $\mathrm{Na}^{+} \mathrm{K}^{+}$ATPase, which is considered to be important for $\mathrm{Na}^{+}, \mathrm{K}^{+}$balance between the plasma membrane. $\mathrm{Na}^{+} \mathrm{K}^{+}$ATPase binds with the ligand binding domain of all $\mathrm{IP}_{3} \mathrm{R}$ isoforms and stimulates $\mathrm{IP}_{3} \mathrm{R}$ in the presence of ouabain. (Zhang et al. 2006). Protein phosphatases (PPI and PP2A) are found to be associated with $\mathrm{IP}_{3} \mathrm{R} 1$ and also cAMP-dependent protein kinase and these molecules are considered to form macromolecular signaling complex (DeSouza et al. 2002). RACK1 serves as a scaffold, linking protein kinase $\mathrm{C}$ to its substrates. RACK1 physiologically binds $\mathrm{IP}_{3}$ receptors and regulates $\mathrm{Ca}^{2+}$ release by enhancing $\mathrm{IP}_{3}$ receptor binding affinity for $\mathrm{IP}_{3}$ (Patterson et al. 2004). Ankyrin $B$ interacts with $I P_{3} R$ in high affinity and this association is important for the $\mathrm{IP}_{3} \mathrm{R}$ posttranslational stability (Mohler et al. 2004). Ankyrin B also binds to $\mathrm{Na}^{+}, \mathrm{K}^{+}$ATPase and $\mathrm{Na}^{+} / \mathrm{Ca}^{2+}$ exchanger 1 and is considered to play a role for cytosolic $\mathrm{Ca}^{2+}$ modulation (Mohler, Davis and Bennett 2005). Chromogranin A and B interact in a pH-dependent manner with $\mathrm{IP}_{3} \mathrm{R}$ between the pore region and transmembrane 6 and stimulate $\mathrm{IP}_{3} \mathrm{R}$ activity (Choe et al. 2004). CARP (carbonic anhydrase-related protein) is specifically expressed in the Purkinje cells in the cerebellum binds to a central part of the molecule between the $\mathrm{IP}_{3}$-binding core and the channel region and CARP reduces the affinity of $\mathrm{IP}_{3} \mathrm{R} 1$ to $\mathrm{IP}_{3}$ (Hirota et al. 2003). Bcl2 and Bcl-X1 are anti-apoptotic proteins which interact with all $\mathrm{IP}_{3} \mathrm{Rs}$ (Chen et al. 2004; Monaco et al. 2012; Rong et al. 2008; White et al. 2005)

\section{3) New signaling molecule, IRBIT, released from $\mathrm{IP}_{3}$ receptor}

The function of $\mathrm{IP}_{3} \mathrm{R}$ was considered only to release $\mathrm{Ca}^{2+}$ through $\mathrm{Ca}^{2+}$ channel. However, it was found that in addition to $\mathrm{Ca}^{2+}$ release, IRBIT ( $\underline{\mathrm{IP}}_{3}$ receptor binding protein released with inositol trisphosphate) (Ando et al. 2006; Ando et al. 2003; Mikoshiba 2007a) was discovered from the analysis of the proteins that associate with $\mathrm{IP}_{3}$ receptor (Fig. 2). Column with native $\mathrm{IP}_{3}$ receptor was incubated with the soluble brain fraction and eluted step-wise increase of salt concentration, and finally eluted with the $\mathrm{IP}_{3}$ with high salt concentration. A single protein was eluted and

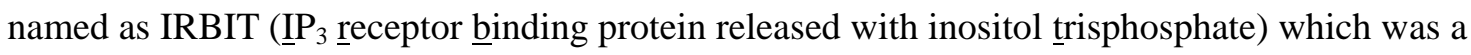
homolog of S-adenosyl homocysteine hydrolase (SAHH) (Ando et al. 2006; Ando et al. 2003) 
having phosphorylated site at the N-terminal region of IRBIT with about 50\% homology with SAHH. It does not exhibit SAHH activity. IRBIT binds to the $\mathrm{IP}_{3}$ binding pocket of the $\mathrm{IP}_{3}$ receptor. Phosphorylated phosphates are required for the binding. And the several amino acids required for the recognition of $\mathrm{IP}_{3}$ is required for the $\mathrm{IP}_{3}$ binding and any single mutation results in the absence of binding to the $\mathrm{IP}_{3}$ binding pocket. Therefore, IRBIT may be considered to be the pseudo-ligand for $\mathrm{IP}_{3}$. IRBIT worked as a pseudo-ligand and addition of IRBIT results in a decreased $\mathrm{Ca}^{2+}$ release.

At a resting state, IRBIT was found to be associated with the $\mathrm{IP}_{3}$ receptor and when high amount of $\mathrm{IP}_{3}$ was added IRBIT is eluted. Target molecule of IRBIT was found to be $\mathrm{Na}^{+}, \mathrm{HCO}_{3}{ }^{-}$ cotransporter 1 (Shirakabe et al. 2006), CFTR (Yang et al. 2009), and $\mathrm{Na}^{+} \mathrm{H}^{+}$exchanger (Tran et al. 2013). These molecules are found to be important for regulation of $\mathrm{pH}$ balance inside the cell. The data suggest that $\mathrm{IP}_{3} \mathrm{R}$ regulates $\mathrm{pH}$ inside the cell through IRBIT (Ando, Kawaai and Mikoshiba 2014).

IRBIT was reported to bind to Cleavage and Polyadenylation Specificity Factor (CPSF) and regulated polyA addition, thereby IRBIT regulates mRNA synthesis (Kiefer et al. 2009). IRBIT was also reported to be a novel regulator of ribonucleotide reductase in higher eukaryotes (Arnaoutov and Dasso 2014).

\section{Inhibitors of $\mathrm{IP}_{3}$ receptors}

Heparin, 2-aminoethoxydiphenyl borinate (2-APB) (Maruyama et al. 1997) and Xestospongin C (Gafni et al. 1997) are most widely used inhibitors for $\mathrm{IP}_{3}$ Rs. Heparins are sulfated glycosaminoglycans and competitively inhibit $\mathrm{IP}_{3} \mathrm{R}$ by binding to the $\mathrm{IP}_{3}$ binding site. Problems of the heparin are the non-specific effect with other proteins with no permeability to the plasmamembrane.

2-APB is a boron compound and it was discovered by the screening of $\mathrm{IP}_{3}$ receptor inhibitor. It is a membrane permeable compound. 2-APB was also found to block the store operated $\mathrm{Ca}^{2+}$ entry (SOCE) channel activity in addition to $\mathrm{IP}_{3}$ induced $\mathrm{Ca}^{2+}$ releasing activity (Fig. 3: left) (Gregory, Rychkov and Barritt 2001; Iwasaki et al. 2001; Kukkonen, Lund and Akerman 2001; Ma et al. 2001; Prakriya and Lewis 2001) (see detailed review on 2-APB in Cell Calcium 2010 (Goto et al. 2010)

By modifying the 2-APB structure, various compounds were synthesized by organic chemistry, drugs that block the SOCE channel was finally developed as DBP 162AE, DBP163AE after 
intensive screening (Goto et al. 2010).

Xestospondin is an extracted compounds and the structure seems similar to 2-APB with two phenol rings (Fig. 3: right) (Gafni et al. 1997). This compound is also membrane permeable and is also used often as 2-APB.

There is still a problem of specificity in both 2-APB and Xestospongin C (Parys and Smedt 2012)

Recently, $\mathrm{IP}_{3}$ sponge which is made from the $\mathrm{IP}_{3}$ binding core of $\mathrm{IP}_{3} \mathrm{R}$ after some mutations of the amino acid of the $\mathrm{IP}_{3}$ binding core is used as an $\mathrm{IP}_{3}$ absorbent (Uchiyama et al. 2002). $\mathrm{IP}_{3}$ sponge inhibits the sugar taste sensation in Drosophila (Usui-Aoki et al. 2005) and blocks fertilization when it is injected to oocytes (Iwasaki et al. 2002). Transgenic mouse which express $\mathrm{IP}_{3}$ sponge in an astrocyte specific manner attenuated the $\mathrm{IP}_{3}$ induced $\mathrm{Ca}^{2+}$ release. The transgenic mice exhibited behavioral impairments in spatial reference memory and remote contextual fear memory (Tanaka et al. 2013).

By taking good use of these inhibitors, it is possible to study the role of $\mathrm{IP}_{3}$ induced $\mathrm{Ca}^{2+}$ release in cell signaling.

\section{Role of each isoform of $I_{3} R$ in cell signaling}

As above mentioned, molecules are expressed in a cell type-specific manner and bind to each isoform in an isoform specific manner. Since the size of the $\mathrm{IP}_{3} \mathrm{R}$, especially the site between the $\mathrm{IP}_{3}$ binding site and transmembrane channel pore region is long, it is plausible to consider that $\mathrm{IP}_{3} \mathrm{R}$ offers a platform for various molecules to interact each other. Three different platforms may offer different trajectories of cell signaling. Various disease states occur depending upon which $\mathrm{IP}_{3} \mathrm{R}$ subtype and signaling trajectory is abnormal.

$\mathrm{IP}_{3} \mathrm{R} 1$ is essential for $\mathrm{Ca}^{2+}$ oscillations in egg and important for fertilization. $\mathrm{IP}_{3} \mathrm{R} 1$ determines the fate of abdomen and back at early developmental stages. $\mathrm{IP}_{3} \mathrm{R} 1$ is involved in neurite extension and neural plasticity. Absence of $\mathrm{IP}_{3} \mathrm{R} 1$ causes abnormal fertilization (Miyazaki et al. 1992) and dorso-ventral axis formation at early stages (Takei et al. 1998). Severe ataxia is caused by $\mathrm{IP}_{3} \mathrm{R} 1$ mutations in humans and mice (Matsumoto et al. 1996; Tada, Nishizawa and Osamu 2014). Blockade of $\mathrm{IP}_{3} \mathrm{R} 1$ caused by ER stress and susceptibility to brain damage (Higo et al. 2010). $\mathrm{IP}_{3} \mathrm{R} 2$ is enriched in heart and overexpression in heart results in hypertrophy of cardiac muscle. This cardiac hypertrophy is rescued by introducing $\mathrm{IP}_{3}$ sponge peptide that trap $\mathrm{IP}_{3}$ (Nakayama et al. 2010). $I P_{3} R 2$ mutation in human-being results in anhydrosis (Klar et al. 2014). $I_{3} R 1$ and $\mathrm{IP}_{3} \mathrm{R} 3$ double knock out mice die due to cardiogenesis arrest at E15 at particular region such as 
outflow tract region of heart accompanied with Mef2C-Smyd1 signaling pathway abnormality (Nakazawa et al. 2011). $\mathrm{IP}_{3} \mathrm{R} 1$ and $\mathrm{IP}_{3} \mathrm{R} 2$ double knock out mice shows defects of the atrioventricular canal and ventricular myocardium of the heart due to the calcineurin/NFAT signaling abnormality. They die at about E15 (Uchida et al. 2010).

The IP ${ }_{3} \mathrm{R} 3$ deficiency results in abnormalities in taste perception(Hisatsune et al. 2007), hair growth cycling (Sato-Miyaoka et al. 2012), and osteoclast formation (Kuroda et al. 2012)., and also results in nasal inflammation(Fukuda et al. 2008). Therefore, it is concluded that $I_{3} R 3$ is important for taste perception, nasal formation, and hair growth and osteoclast formation. $\mathrm{IP}_{3} \mathrm{R} 2$ and $\mathrm{IP}_{3} \mathrm{R} 3$ are important for exocrine fluid secretion including saliva, pancreatic juice (Futatsugi et al. 2005) and tear secretion (Inaba et al. 2014). $\mathrm{IP}_{3} \mathrm{R} 2$ and $\mathrm{IP}_{3} \mathrm{R} 3$ double knockout results in dry eye and dry mouth and pancreatic juice secretion deficit (Futatsugi et al. 2005). These phenotypes are those of Sjögren Syndrome which is an autoimmune diseases. The antisera from autoimmune disease patients were collected and analysed and were found that antisera from autoimmune patients contain anti-IP ${ }_{3} R$ antibodies (Miyachi et al. 2009). Therefore, detection of the antibody against $\mathrm{IP}_{3} \mathrm{R}$ in the sera from the candidate of autoimmune disease patients could be considered to be a good candidate for the one of the diagnostic tool of autoimmune disease.

Evidently, each $\mathrm{IP}_{3} \mathrm{R}$ type plays a specific role as a signaling hub by association with various molecules and this in turn determines its trajectory of cell signaling and function (Fig. 4). The detailed mechanisms how these delicate differences should be further analyzed, but it is clear that each $\mathrm{IP}_{3} \mathrm{R}$ produces diversified cell signaling paths from a single $\mathrm{IP}_{3} \mathrm{R}$ molecule. Therefore, when there occurs an abnormality in $\mathrm{IP}_{3}$ receptor, abnormal cell function occurs resulting in severe diseases (Berridge 1998; Foskett 2010; Hara and Snyder 2007; Mikoshiba 2007a; Patterson, Boehning and Snyder 2004).

cDNA cloning of Trypanosoma Cruzi $\mathrm{IP}_{3}$ receptor, and detection of $\mathrm{Ca}^{2+}$ oscillation in Malaria (Plasmodium Falciparum) worm

Analysis of primitive living organisms sometimes demonstrates us the essence of life and principle of the phenomena.

cDNA of $\mathrm{IP}_{3}$ receptor of Trypanosoma Cruzi was cloned and sequenced. It was a single gene. Knock down or overexpression of the receptor resulted in death of the worm suggesting delicate amount of $\mathrm{IP}_{3}$ receptor is essential for the worm for surviving (Hashimoto et al. 2013). Since the 
$\mathrm{IP}_{3}$ receptor of Trypanosoma Cruzi is different from other species including human-being, antisense oligonucleotides strategy targeting parasite $\mathrm{IP}_{3}$ receptor works quite efficiently to inhibit mammalian host cell invasion by the worm (Hashimoto et al. 2013).

The spontaneous $\mathrm{Ca}^{2+}$ oscillation of the parasite of Plasmodium Falciparum was observed in the intraerythrocytic Plasmodium Falciparum, and 2-APB blocked the $\mathrm{Ca}^{2+}$ oscillation and resulted in the death of the worm suggesting $\mathrm{Ca}^{2+}$ oscillation is essential for the Plasmodium Falciparum for the survival of the worm (Enomoto et al. 2012).

\section{In summary}

$\mathrm{IP}_{3}$ receptor is now considered to be an important signaling molecule. Biochemical and molecular biological studies including the primary amino acid sequence and three dimensional structure helped us to understand the mechanism of $\mathrm{IP}_{3}$ receptor that exerts multiple functions. It is found from the various evidences that $\mathrm{IP}_{3}$ receptor is working as a signaling hub for the cell signaling. Each type of $\mathrm{IP}_{3}$ receptor has its own signaling hub that determines different trajectories of cell signaling resulting a variety of cell functions assisted by calcium oscillation. Dysregulation of $\mathrm{IP}_{3}$ receptor causes severe diseases in human and rodents.

\section{Acknowledgments}

The work was supported by the RIKEN BSI Grant, RIKEN President's Fund, Japan Society for the Promotion of Science Grants-in-Aid for Scientific Research S (25221002), JST

(ICORP-SORST) project

Fig 1

$\mathrm{IP}_{3}-\mathrm{IP}_{3}$ receptor and Diacylglycerol (DAG)-Protein Kinase C (PKC) signaling system. $\mathrm{IP}_{3}$ binds to $\mathrm{IP}_{3}$ receptor and releases $\mathrm{Ca}^{2+}$ from intracellular stores and also releases IRBIT from the $\mathrm{IP}_{3}$ binding core of $\mathrm{IP}_{3}$ receptor. DAG activates $\mathrm{PKC}$ and $\mathrm{PKC}$ regulates various molecules by phosphorylation.

Fig. 2

$\operatorname{IRBIT}\left(\underline{\operatorname{IP}} \underline{\mathrm{R}}_{\underline{R}} \underline{b}\right.$ inding protein released with $\underline{i n o s i t o l} 1,4,5$-trisphosphate) is a pseudo-ligand of $I P_{3}$ receptor.

IRBIT binds to the $\mathrm{IP}_{3}$ binding core and released in the presence of high concentration of $\mathrm{IP}_{3}$. The amino acids necessary for the recognition of $\mathrm{IP}_{3}$ are also necessary for the recognition of 
IRBIT (Ando et al. 2006; Ando et al. 2003). Phosphorylation of IRBIT is required to be recognized by the $\mathrm{IP}_{3} \mathrm{R}$. IRBIT suppresses $\mathrm{IP}_{3}$ induced $\mathrm{Ca}^{2+}$ release but when IRBIT is treated by siRNA, amplitude and frequency of $\mathrm{Ca}^{2+}$ oscillation were enhanced.

Fig. 3

\section{Structure of 2-APB (left) and Xestospongin $\mathrm{C}$ (right) which are $\mathrm{IP}_{3}$ receptor inhibitor}

Fig. 4 Each $I_{3} R$ has each different signaling hub for the cell regulation assisted by calcium oscillation.

Three isoforms of $\mathrm{IP}_{3} \mathrm{R}$ determine the trajectory for cell signaling inside the cell. : Three types of $\mathrm{IP}_{3} \mathrm{R}$ cDNA are cloned and the whole sequences are determined in vertebrate (mouse, rat and human-being). There are various structural differences in phosphorylation sites, glycosylation sites, splicing sites and also the sequence itself. In addition, each isoform has different $\mathrm{IP}_{3}$ binding affinity. 5' promoter region of cDNA of each isoform is different suggesting that the each isoform has its cell type specific expression pattern. As is well described in the text (see the section of " $\mathrm{IP}{ }_{3} \mathrm{R}$ works as a signaling hub for diversified cell function") each isoform forms macro-molecular complex which works as a signaling hub by association with various molecules and determines the direction of cell signaling pathways. Various diseases occur depending upon which $\mathrm{IP}_{3} \mathrm{R}$ is abnormal.

Traditional concept is that the $\mathrm{Ca}^{2+}$ determines all the various functions based on the $\mathrm{Ca}^{2+}$ oscillation. According to the novel concept, each isoform among three isoforms determine the different trajectory of cell signaling assisted with the $\mathrm{Ca}^{2+}$ signaling including $\mathrm{Ca}^{2+}$ oscillation.

\section{References}

Ando, H., K. Kawaai, and K. Mikoshiba. 2014. "IRBIT: a regulator of ion channels and ion transporters." Biochim Biophys Acta. 1843(10):2195-204. .

Ando, H., A. Mizutani, H. Kiefer, D. Tsuzurugi, T. Michikawa, and K. Mikoshiba. 2006. "IRBIT suppresses $\mathrm{IP}_{3}$ receptor activity by competing with $\mathrm{IP}_{3}$ for the common binding site on the $\mathrm{IP}_{3}$ receptor." Mol Cell 22(6):795-806. 
Ando, H., A. Mizutani, T. Matsu-ura, and K. Mikoshiba. 2003. "IRBIT, a novel inositol 1,4,5-trisphosphate (IP3) receptor-binding protein, is released from the IP3 receptor upon IP3 binding to the receptor." $J$ Biol Chem 278(12):10602-12.

Arnaoutov, A., and M. Dasso. 2014. "Enzyme regulation. IRBIT is a novel regulator of ribonucleotide reductase in higher eukaryotes." Science. 345(6203):1512-5. .

Berridge, M. J. 1998. "Neuronal calcium signaling." Neuron. 21(1):13-26.

Bezprozvanny, I., J. Watras, and B.E. Ehrlich. 1991. "Bell-shaped calcium-response curves of Ins $(1,4,5) \mathrm{P} 3-$ and calcium-gated channels from endoplasmic reticulum of cerebellum." Nature 351(6329):751-4.

Boehning, D., R. L. Patterson, L. Sedaghat, N. O. Glebova, T. Kurosaki, and S. H. Snyder. 2003. "Cytochrome c binds to inositol $(1,4,5)$ trisphosphate receptors, amplifying calcium-dependent apoptosis." Nat Cell Biol. 5(12):1051-61. Epub 2003 Nov 9.

Carafoli, Ernesto, and Claude Klee. 1999. Calcium as a cellular regulator: Oxford.

Chadwick, C. C., A. Saito, and S. Fleischer. 1990. "Isolation and characterization of the inositol trisphosphate receptor from smooth muscle." Proc Natl Acad Sci US A 87(6):2132-6.

Chen, R., I. Valencia, F. Zhong, K. S. McColl, H. L. Roderick, M. D. Bootman, M. J. Berridge, S. J. Conway, A. B. Holmes, G. A. Mignery, P. Velez, and C. W. Distelhorst. 2004. "Bcl-2 functionally interacts with inositol 1,4,5-trisphosphate receptors to regulate calcium release from the ER in response to inositol 1,4,5-trisphosphate." Journal of Cell Biology 166(2):193-203.

Choe, C. U., K. D. Harrison, W. Grant, and B. E. Ehrlich. 2004. "Functional coupling of chromogranin with the inositol 1,4,5-trisphosphate receptor shapes calcium signaling." J Biol Chem. 279(34):35551-6.

Crepel, F., J.L. Dupont, and R. Gardette. 1984. "Selective absence of calcium spikes in Purkinje cells of staggerer mutant mice in cerebellar slices maintained in vitro." J Physiol. 346:111-25.

Dal Santo, P., M. A. Logan, A. D. Chisholm, and E. M. Jorgensen. 1999. "The 
inositol trisphosphate receptor regulates a 50-second behavioral rhythm in C. elegans." Cell 98(6):757-67.

DeSouza, N., S. Reiken, K. Ondrias, Y. M. Yang, S. Matkovich, and A. R. Marks. 2002. "Protein kinase A and two phosphatases are components of the inositol 1,4,5-trisphosphate receptor macromolecular signaling complex." J Biol Chem 277(42):39397-400.

Enomoto, M., S. Kawazu, S. Kawai, W. Furuyama, T. Ikegami, J. Watanabe, and K. Mikoshiba. 2012. "Blockage of spontaneous $\mathrm{Ca}^{2+}$ oscillation causes cell death in intraerythrocitic Plasmodium falciparum." PLoS One 7(7):e39499.

Ferris, C. D., R. L. Huganir, and S. H. Snyder. 1990. "Calcium flux mediated by purified inositol 1,4,5-trisphosphate receptor in reconstituted lipid vesicles is allosterically regulated by adenine nucleotides." Proc Natl Acad Sci U S A. 87(6):2147-51.

Foskett, J. K. 2010. "Inositol trisphosphate receptor Ca2+ release channels in neurological diseases." Pflugers Arch. 460(2):481-94. doi: 10.1007/s00424-010-0826-0. Epub 2010 Apr 10.

Foskett, J. K., C. White, K. H. Cheung, and D. O. Mak. 2007. "Inositol trisphosphate receptor $\mathrm{Ca}^{2+}$ release channels." Physiol Rev. 87(2):593-658.

Fukuda, N., M. Shirasu, K. Sato, E. Ebisui, K. Touhara, and K. Mikoshiba. 2008. "Decreased olfactory mucus secretion and nasal abnormality in mice lacking type 2 and type 3 IP3 receptors." Eur $J$ Neurosci. 27(10):2665-75.

Furuichi, T., K. Kohda, A. Miyawaki, and K. Mikoshiba. 1994. "Intracellular channels." Curr Opin Neurobiol 4(3):294-303.

Furuichi, T., S. Yoshikawa, and K. Mikoshiba. 1989. "Nucleotide sequence of cDNA encoding P400 protein in the mouse cerebellum." Nucleic Acids Res 17(13):5385-6.

Furuichi, T., S. Yoshikawa, A. Miyawaki, K. Wada, N. Maeda, and K. Mikoshiba. 1989. "Primary structure and functional expression of the inositol 1,4,5-trisphosphate-binding protein P400." Nature 342(6245):32-8. 
Futatsugi, A., T. Nakamura, M. K. Yamada, E. Ebisui, K. Nakamura, K. Uchida, T. Kitaguchi, H. Takahashi-Iwanaga, T. Noda, J. Aruga, and K. Mikoshiba. 2005. "IP 3 receptor types 2 and 3 mediate exocrine secretion underlying energy metabolism." Science 309(5744):2232-4.

Gafni, J., J. A. Munsch, T. H. Lam, M. C. Catlin, L. G. Costa, T. F. Molinski, and I. N. Pessah. 1997. "Xestospongins: potent membrane permeable blockers of the inositol 1,4,5-trisphosphate receptor." Neuron 19(3):723-33.

Goto, J., A. Z. Suzuki, S. Ozaki, N. Matsumoto, T. Nakamura, E. Ebisui, A. Fleig, R. Penner, and K. Mikoshiba. 2010. "Two novel 2-aminoethyl diphenylborinate (2-APB) analogues differentially activate and inhibit store-operated $\mathrm{Ca}(2+)$ entry via STIM proteins." Cell Calcium. 47(1):1-10. .

Gregory, R. B., G. Rychkov, and G. J. Barritt. 2001. "Evidence that 2 -aminoethyl diphenylborate is a novel inhibitor of store-operated $\mathrm{Ca} 2+$ channels in liver cells, and acts through a mechanism which does not involve inositol trisphosphate receptors." Biochem J. $354(\mathrm{Pt}$ 2):285-90.

Hamada, K., and K. Mikoshiba. 2012. "Revisiting channel allostery: a coherent mechanism in IP(3) and ryanodine receptors." Sci Signal 5(225):pe24.

Hamada, K., T. Miyata, K. Mayanagi, J. Hirota, and K. Mikoshiba. 2002. "Two-state conformational changes in inositol 1,4,5-trisphosphate receptor regulated by calcium." J Biol Chem 277(24):21115-8.

Hamada, K., A. Terauchi, and K. Mikoshiba. 2003. "Three-dimensional rearrangements within inositol 1,4,5-trisphosphate receptor by calcium." J Biol Chem 278(52):52881-9.

Hara, M. R., and S. H. Snyder. 2007. "Cell signaling and neuronal death." Annu Rev Pharmacol Toxicol 47:117-41.

Hasan, G., and M. Rosbash. 1992. "Drosophila homologs of two mammalian intracellular $\mathrm{Ca}(2+)$-release channels: identification and expression patterns of the inositol 1,4,5-triphosphate and the ryanodine receptor genes." Development 116(4):967-75. 
Hashimoto, M., M. Enomoto, J. Morales, N. Kurebayashi, T. Sakurai, T. Hashimoto, T. Nara, and K. Mikoshiba. 2013. "Inositol 1,4,5-trisphosphate receptor regulates replication, differentiation, infectivity and virulence of the parasitic protist Trypanosoma cruzi." Mol Microbiol. 87(6):1133-50. .

Higo, T, K Hamada, C Hisatsune, N Nukina, T Hashikawa, M Hattori, T Nakamura, and K Mikoshiba. 2010. "Mechanism of ER stress-induced brain damage by IP(3) receptor." Neuron 68(5):865-78.

Higo, T., M. Hattori, T. Nakamura, T. Natsume, T. Michikawa, and K. Mikoshiba. 2005. "Subtype-specific and ER lumenal environment-dependent regulation of inositol 1,4,5-trisphosphate receptor type 1 by ERp44." Cell 120(1):85-98.

Hingorani, S. R., and W. S. Agnew. 1991. "A rapid ion-exchange assay for detergent-solubilized inositol 1,4,5- trisphosphate receptors." Anal Biochem 194(1):204-13.

-. 1992. "Assay and purification of neuronal receptors for inositol 1,4,5trisphosphate." Methods Enzymol 207:573-91.

Hirota, J., H. Ando, K. Hamada, and K. Mikoshiba. 2003. "Carbonic anhydrase-related protein is a novel binding protein for inositol 1,4,5-trisphosphate receptor type 1." Biochem J372(Pt 2):435-41.

Hisatsune, C., K. Yasumatsu, H. Takahashi-Iwanaga, N. Ogawa, Y. Kuroda, R. Yoshida, Y. Ninomiya, and K. Mikoshiba. 2007. "Abnormal taste perception in mice lacking the type 3 inositol 1,4,5-trisphosphate receptor." J Biol Chem 282(51):37225-31.

Inaba, T., C. Hisatsune, Y. Sasaki, Y. Ogawa, E. Ebisui, N. Ogawa, M. Matsui, T. Takeuchi, K. Mikoshiba, and K. Tsubota. 2014. "Mice lacking inositol 1,4,5-trisphosphate receptors exhibit dry eye." PLoS One. 9(6):e99205. doi: 10.1371/journal.pone.0099205. eCollection 2014.

Islam, Md. Shahidul. 2012. "Inositol 1,4,5-Triphosphate and Its Receptors." Pp. 1-1267 in Calcium Signaling, edited by Md. Shahidul Islam: Springer.

Iwai, M., T. Michikawa, I. Bosanac, M. Ikura, and K. Mikoshiba. 2007. "Molecular basis of the isoform-specific ligand-binding affinity of 
inositol 1,4,5-trisphosphate receptors." J Biol Chem 282(17):12755-64. Iwai, M., Y. Tateishi, M. Hattori, A. Mizutani, T. Nakamura, A. Futatsugi, T. Inoue, T. Furuichi, T. Michikawa, and K. Mikoshiba. 2005. "Molecular cloning of mouse type 2 and type 3 inositol 1,4,5-trisphosphate receptors and identification of a novel type 2 receptor splice variant." $J$ Biol Chem 280(11):10305-17.

Iwasaki, H., K. Chiba, T. Uchiyama, F. Yoshikawa, F. Suzuki, M. Ikeda, T. Furuichi, and K. Mikoshiba. 2002. "Molecular characterization of the starfish inositol 1,4,5-trisphosphate receptor and its role during oocyte maturation and fertilization." J Biol Chem 277(4):2763-72.

Iwasaki, H., Y. Mori, Y. Hara, K. Uchida, H. Zhou, and K. Mikoshiba. 2001. "2-Aminoethoxydiphenyl borate (2-APB) inhibits capacitative calcium entry independently of the function of inositol 1,4,5-trisphosphate receptors." Receptors Channels 7(6):429-39.

Kawaai, K., C. Hisatsune, Y. Kuroda, A. Mizutani, T. Tashiro, and K. Mikoshiba. 2009. "80K-H interacts with inositol 1,4,5-trisphosphate (IP3) receptors and regulates IP3-induced calcium release activity." $J$ Biol Chem 284(1):372-80.

Kiefer, H., A. Mizutani, S. Iemura, T. Natsume, H. Ando, Y. Kuroda, and K. Mikoshiba. 2009. "Inositol 1,4,5-triphosphate receptor-binding protein released with inositol 1,4,5-triphosphate (IRBIT) associates with components of the mRNA $3^{\prime}$ processing machinery in a phosphorylation-dependent manner and inhibits polyadenylation." $J$ Biol Chem 284(16):10694-705.

Klar, J., C. Hisatsune, S.M. Baig, M. Tariq, A.C.V. Johansson, M. Rasool, N.A. Malik, A. Ameur, K. Sugiura, L. Feuk, K. Mikoshiba, and N. Dahl. 2014. "InsP3R2 mutations cause anhidrosis in humans and hypohidrosis in mice." J. Clin. Invest. in press.

Kukkonen, J. P., P. E. Lund, and K. E. Akerman. 2001. "2-aminoethoxydiphenyl borate reveals heterogeneity in receptor-activated $\mathrm{Ca}(2+)$ discharge and store-operated $\mathrm{Ca}(2+)$ influx." Cell Calcium. 30(2):117-29.

Kume, S., A. Muto, J. Aruga, T. Nakagawa, T. Michikawa, T. Furuichi, S. 
Nakade, H. Okano, and K. Mikoshiba. 1993. "The Xenopus IP3 receptor: structure, function, and localization in oocytes and eggs." Cell 73(3):555-70.

Kuroda, Y., C. Hisatsune, A. Mizutani, N. Ogawa, K. Matsuo, and K. Mikoshiba. 2012. "Cot kinase promotes $\mathrm{Ca} 2+$ oscillation/calcineurin-independent osteoclastogenesis by stabilizing NFATc1 protein." Mol Cell Biol. 32(14):2954-63. doi: 10.1128/MCB.05611-11. Epub 2012 May 21.

Ma, H. T., K. Venkatachalam, H. S. Li, C. Montell, T. Kurosaki, R. L. Patterson, and D. L. Gill. 2001. "Assessment of the role of the inositol 1,4,5-trisphosphate receptor in the activation of transient receptor potential channels and store-operated Ca2+ entry channels." $J$ Biol Chem. 276(22):18888-96. Epub 2001 Mar 19.

Maeda, N., T. Kawasaki, S. Nakade, N. Yokota, T. Taguchi, M. Kasai, and K. Mikoshiba. 1991. "Structural and functional characterization of inositol 1,4,5-trisphosphate receptor channel from mouse cerebellum." Journal of Biological Chemistry 266(2):1109-16.

Maeda, N., M. Niinobe, Y. Inoue, and K. Mikoshiba. 1989. "Developmental expression and intracellular location of $\mathrm{P} 400$ protein characteristic of Purkinje cells in the mouse cerebellum." Dev Biol 133(1):67-76.

Maeda, N., M. Niinobe, K. Nakahira, and K. Mikoshiba. 1988. "Purification and characterization of $\mathrm{P} 400$ protein, a glycoprotein characteristic of Purkinje cell, from mouse cerebellum." J Neurochem 51(6):1724-30.

Maruyama, T., T. Kanaji, S. Nakade, T. Kanno, and K. Mikoshiba. 1997. "2APB, 2-aminoethoxydiphenyl borate, a membrane-penetrable modulator of Ins $(1,4,5) \mathrm{P} 3$-induced Ca2+ release." J Biochem (Tokyo) 122(3):498-505.

Matsumoto, M., T. Nakagawa, T. Inoue, E. Nagata, K. Tanaka, H. Takano, O. Minowa, J. Kuno, S. Sakakibara, M. Yamada, H. Yoneshima, A. Miyawaki, Y. Fukuuchi, T. Furuichi, H. Okano, K. Mikoshiba, and T. Noda. 1996. "Ataxia and epileptic seizures in mice lacking type 1 inositol 1,4,5- trisphosphate receptor." Nature 379(6561):168-71.

Mignery, G. A., C.L. Newton, B.T. Archer, and T. C. Sudhof. 1990. "Structure 
and expression of the rat inositol 1,4,5-trisphosphate receptor." J. Biol. Chem. 265:12679-85.

Mignery, G. A., T. C. Sudhof, K. Takei, and P. De Camilli. 1989. "Putative receptor for inositol 1,4,5-trisphosphate similar to ryanodine receptor." Nature 342:192-5.

Mikoshiba, K. 2007a. "IP 3 receptor/ $\mathrm{Ca}^{2+}$ channel: from discovery to new signaling concepts." J Neurochem 102(5):1426-46.

-. 2007b. "IP $\mathrm{IP}_{3}$ receptors and their role in cell function." Pp. 267-85 in CALCIUM: A Matter of Life or Death, edited by J. Krebs and M. Michalak: Elsevier.

-. 2012. "The discovery and structural investigation of the $\mathrm{IP}_{3}$ receptor and associated IRBIT protein." Pp. 281-304 in Calcium Signaling, edited by Md. Shahidul Islam: Springer.

Mikoshiba, K., M. Huchet, and J. P. Changeux. 1979. "Biochemical and immunological studies on the $\mathrm{P} 400$ protein, a protein characteristic of the Purkinje cell from mouse and rat cerebellum." Dev Neurosci 2(6):254-75.

Miyachi, K., RW. Hankins, Y. Uehara, B. Zhang, K. Saku, Y. Homma, H. Shigematsu, and K. Mikoshiba. 2009. "A postmenopausal patient with Tangier disease developing Sjogren's syndrome." $J$ Rheumatol. 36(1):208-10. doi: 10.3899/jrheum.080417.

Miyawaki, A., T. Furuichi, N. Maeda, and K. Mikoshiba. 1990. "Expressed cerebellar-type inositol 1,4,5-trisphosphate receptor, $\mathrm{P} 400$, has calcium release activity in a fibroblast L cell line." Neuron 5(1):11-8.

Miyazaki, S., M. Yuzaki, K. Nakada, H. Shirakawa, S. Nakanishi, S. Nakade, and K. Mikoshiba. 1992. "Block of Ca2+ wave and Ca2+ oscillation by antibody to the inositol 1,4,5-trisphosphate receptor in fertilized hamster eggs." Science 257(5067):251-5.

Mohler, P. J., J. Q. Davis, and V. Bennett. 2005. "Ankyrin-B coordinates the $\mathrm{Na} / \mathrm{K}$ ATPase, $\mathrm{Na} / \mathrm{Ca}$ exchanger, and InsP3 receptor in a cardiac T-tubule/SR microdomain." PLoS Biol. 3(12):e423. .

Mohler, P. J., J. Q. Davis, L. H. Davis, J. A. Hoffman, P. Michaely, and V. Bennett. 2004. "Inositol 1,4,5-trisphosphate receptor localization and 
stability in neonatal cardiomyocytes requires interaction with ankyrin-B." J Biol Chem. 279(13):12980-7. .

Monaco, G., E. Decrock, H. Akl, R. Ponsaerts, T. Vervliet, T. Luyten, M. De Maeyer, L. Missiaen, C. W. Distelhorst, H. De Smedt, J. B. Parys, L. Leybaert, and G. Bultynck. 2012. "Selective regulation of IP3-receptor-mediated $\mathrm{Ca} 2+$ signaling and apoptosis by the $\mathrm{BH} 4$ domain of Bcl-2 versus Bcl-Xl." Cell Death and Differentiation 19(2):295-309.

Monkawa, T., A. Miyawaki, T. Sugiyama, H. Yoneshima, M. Yamamoto-Hino, T. Furuichi, T. Saruta, M. Hasegawa, and K. Mikoshiba. 1995. "Heterotetrameric complex formation of inositol 1,4,5-trisphosphate receptor subunits." J Biol Chem. 270(24):14700-4.

Mourey, R. J., A. Verma, S. Supattapone, and S. H. Snyder. 1990. "Purification and characterization of the inositol 1,4,5- trisphosphate receptor protein from rat vas deferens." Biochem J 272(2):383-9.

Nakayama, H, I Bodi, M Maillet, J DeSantiago, TL Domeier, K Mikoshiba, JN Lorenz, LA Blatter, DM Bers, and JD Molkentin. 2010. "The $\mathrm{IP}_{3}$ receptor regulates cardiac hypertrophy in response to select stimuli." Circ Res. 107(5):659-66.

Nakazawa, M., K. Uchida, M. Aramaki, K. Kodo, C. Yamagishi, T. Takahashi, K. Mikoshiba, and H. Yamagishi. 2011. "Inositol 1,4,5-trisphosphate receptors are essential for the development of the second heart field." $J$ Mol Cell Cardiol. 51(1):58-66. .

Nordquist, D. T., C. A. Kozak, and H. T. Orr. 1988. "cDNA cloning and characterization of three genes uniquely expressed in cerebellum by Purkinje neurons." J Neurosci 8(12):4780-9.

Otsu, H., A. Yamamoto, N. Maeda, K. Mikoshiba, and Y. Tashiro. 1990. "Immunogold localization of inositol 1, 4, 5-trisphosphate (InsP3) receptor in mouse cerebellar Purkinje cells using three monoclonal antibodies." Cell Struct Funct 15(3):163-73.

Parys, J. B., S. W. Sernett, S. DeLisle, P. M. Snyder, M. J. Welsh, and K. P. Campbell. 1992. "Isolation, characterization, and localization of the inositol $1,4,5^{-}$trisphosphate receptor protein in Xenopus laevis 
oocytes." J Biol Chem 267(26):18776-82.

Parys, J.B., and H.D Smedt. 2012. "Inositol 1,4,5-Triphosphate and Its Receptors." Pp. 255-79 in Calcium Signaling: Springer.

Patterson, R. L., D. Boehning, and S. H. Snyder. 2004. "Inositol 1,4,5-trisphosphate receptors as signal integrators." Annu Rev Biochem 73:437-65.

Patterson, R. L., D. B. van Rossum, R. K. Barrow, and S. H. Snyder. 2004. "RACK1 binds to inositol 1,4,5-trisphosphate receptors and mediates Ca2+ release." Proc Natl Acad Sci U S A. 101(8):2328-32.

Pochet, Roland 2000. CALCIUM The molecular basis of calcium action in biology and medicine: Kluwer academic publishers.

Prakriya, M., and R. S. Lewis. 2001. "Potentiation and inhibition of $\mathrm{Ca}(2+)$ release-activated $\mathrm{Ca}(2+)$ channels by 2 -aminoethyldiphenyl borate (2-APB) occurs independently of IP(3) receptors." J Physiol. 536(Pt 1):3-19.

Prentki, M., T. J. Biden, D. Janjic, R. F. Irvine, M. J. Berridge, and C. B. Wollheim. 1984. "Rapid mobilization of $\mathrm{Ca} 2+$ from rat insulinoma microsomes by inositol-1,4,5-trisphosphate." Nature 309(5968):562-4.

Rong, Y.P., A.S. Aromolaran, G. Bultynck, F. Zhong, X. Li, K. McColl, S. Matsuyama, S. Herlitze, H. L. Roderick, M.D. Bootman, G.A. Mignery, J.B. Parys, H. De Smedt, and C.W. Distelhorst. 2008. "Targeting Bcl-2-IP3 receptor interaction to reverse Bcl-2's inhibition of apoptotic calcium signals." Molecular Cell 31(2):255-65.

Sato-Miyaoka, M., C. Hisatsune, E. Ebisui, N. Ogawa, H. Takahashi-Iwanaga, and K. Mikoshiba. 2012. "Regulation of hair shedding by the type 3 IP3 receptor." $J$ Invest Dermatol. 132(9):2137-47. .

Satoh, T., C. A. Ross, A. Villa, S. Supattapone, T. Pozzan, S. H. Snyder, and J. Meldolesi. 1990. "The inositol 1,4,5,-trisphosphate receptor in cerebellar Purkinje cells: quantitative immunogold labeling reveals concentration in an ER subcompartment." J Cell Biol. 111(2):615-24.

Shinohara, T., T. Michikawa, M. Enomoto, J. Goto, M. Iwai, T. Matsu-ura, H. Yamazaki, A. Miyamoto, A. Suzuki, and K. Mikoshiba. 2011. 
"Mechanistic basis of bell-shaped dependence of inositol 1,4,5-trisphosphate receptor gating on cytosolic calcium." Proc Natl Acad Sci 108(37):15486-91. .

Shirakabe, K., G. Priori, H. Yamada, H. Ando, S. Horita, T. Fujita, I. Fujimoto, A. Mizutani, G. Seki, and K. Mikoshiba. 2006. "IRBIT, an inositol 1,4,5-trisphosphate receptor-binding protein, specifically binds to and activates pancreas-type $\mathrm{Na}+\mathrm{HCO} 3^{-}$cotransporter 1 (pNBC1)." Proc Natl Acad Sci U S A. 103(25):9542-7.

Signal, Proceedings of the Yamada Conference XXXIX on Calcium as Cell. 1995. Calcium as Cell Signal. Tokyo, New York: IGAKU-SHOIN.

Spat, A., P. G. Bradford, J. S. McKinney, R. P. Rubin, and J. W. Putney, Jr. 1986. "A saturable receptor for 32P-inositol-1,4,5-triphosphate in hepatocytes and neutrophils." Nature 319(6053):514-6.

Streb, H., R. F. Irvine, M. J. Berridge, and I. Schulz. 1983. "Release of Ca2+ from a nonmitochondrial intracellular store in pancreatic acinar cells by inositol-1,4,5-trisphosphate." Nature 306(5938):67-9.

Sudhof, T. C., C. L. Newton, B. T. Archer, 3rd, Y. A. Ushkaryov, and G. A. Mignery. 1991. "Structure of a novel $\operatorname{InsP}_{3}$ receptor." $E M B O J$ 10(11):3199-206.

Südhof, T.C., C.L. Newton, 3rd. Archer B.T, Y.A. Ushkaryov, and G.A. Mignery. 1991. "Structure of a novel InsP3 receptor." EMBO J. 10(11):3199-206.

Supattapone, S., P. F. Worley, J. M. Baraban, and S. H. Snyder. 1988. "Solubilization, purification, and characterization of an inositol trisphosphate receptor." Journal of Biological Chemistry 263(3):1530-34.

Tada, M., M Nishizawa, and O. Osamu. 2014. "IP3 receptors in neurological disorders." in Pathologies of Calcium Channels, edited by Norbert Weiss, Koschak, Alexandra: Springer.

Takei, K., R. M. Shin, T. Inoue, K. Kato, and K. Mikoshiba. 1998. "Regulation of nerve growth mediated by inositol 1,4,5-trisphosphate receptors in growth cones." Science 282(5394):1705-8.

Takeshima, H., S. Nishimura, T. Matsumoto, H. Ishida, K. Kangawa, N. 
Minamino, H. Matsuo, M. Ueda, M. Hanaoka, T. Hirose, and et al. 1989. "Primary structure and expression from complementary DNA of skeletal muscle ryanodine receptor." Nature 339(6224):439-45.

Tanaka, M., P. Y. Shih, H. Gomi, T. Yoshida, J. Nakai, R. Ando, T. Furuichi, K. Mikoshiba, A. Semyanov, and S. Itohara. 2013. "Astrocytic Ca2+ signals are required for the functional integrity of tripartite synapses." Mol Brain. 6:6.(doi):10.1186/756-6606-6-6.

Tang, T. S., H. Tu, E. Y. Chan, A. Maximov, Z. Wang, C. L. Wellington, M. R. Hayden, and I. Bezprozvanny. 2003. "Huntingtin and huntingtin-associated protein 1 influence neuronal calcium signaling mediated by inositol-(1,4,5) triphosphate receptor type 1." Neuron. 39(2):227-39.

Tran, T. M., M. Y. Park, J. Lee, J. S. Bae, S. M. Hwang, S. Y. Choi, K. Mikoshiba, and K. Park. 2013. "IRBIT plays an important role in NHE3-mediated pHi regulation in HSG cells." Biochem Biophys Res Commun. 437(1):18-22. .

Uchida, K., M. Aramaki, M. Nakazawa, C. Yamagishi, S. Makino, K. Fukuda, T. Nakamura, T. Takahashi, K. Mikoshiba, and H. Yamagishi. 2010. "Gene knock-outs of inositol 1,4,5-trisphosphate receptors types 1 and 2 result in perturbation of cardiogenesis." PLoS One 5(9):e12500.

Uchida, K., H. Miyauchi, T. Furuichi, T. Michikawa, and K. Mikoshiba. 2003. "Critical regions for activation gating of the inositol 1,4,5-trisphosphate receptor." J Biol Chem 278(19):16551-60.

Uchiyama, T., F. Yoshikawa, A. Hishida, T. Furuichi, and K. Mikoshiba. 2002. "A novel recombinant hyperaffinity inositol 1,4,5-trisphosphate (IP(3)) absorbent traps IP(3), resulting in specific inhibition of IP(3)-mediated calcium signaling." J Biol Chem. 277(10):8106-13. Epub 2001 Dec 7.

Usui-Aoki, K., K. Matsumoto, M. Koganezawa, S. Kohatsu, K. Isono, H. Matsubayashi, M. T. Yamamoto, R. Ueda, K. Takahashi, K. Saigo, K. Mikoshiba, and D. Yamamoto. 2005. "Targeted expression of Ip3 sponge and Ip3 dsRNA impaires sugar taste sensation in Drosophila." J Neurogenet. 19(3-4):123-41.

White, C., C. Li, J. Yang, N. B. Petrenko, M. Madesh, C. B. Thompson, and J. 
K. Foskett. 2005. "The endoplasmic reticulum gateway to apoptosis by Bcl-X-L modulation of the InsP(3)R." Nature Cell Biology 7(10):1021-U135.

Yamada, N., Y. Makino, R. A. Clark, D. W. Pearson, M. G. Mattei, J. L. Guenet, E. Ohama, I. Fujino, A. Miyawaki, T. Furuichi, and et al. 1994. "Human inositol 1,4,5-trisphosphate type-1 receptor, $\operatorname{InsP}_{3} R 1$ : structure, function, regulation of expression and chromosomal localization." Biochem J 302:781-90.

Yamamoto, A., H. Otsu, T. Yoshimori, N. Maeda, K. Mikoshiba, and Y. Tashiro. 1991. "Stacks of flattened smooth endoplasmic reticulum highly enriched in inositol 1,4,5-trisphosphate (InsP3) receptor in mouse cerebellar Purkinje cells." Cell Struct Funct 16(5):419-32.

Yamamoto-Hino, M., T. Sugiyama, K. Hikichi, M. G. Mattei, K. Hasegawa, S. Sekine, K. Sakurada, A. Miyawaki, T. Furuichi, M. Hasegawa, and K. Mikoshiba. 1994. "Cloning and characterization of human type 2 and type 3 inositol 1, 4, 5-trisphosphate receptors." Receptors and Channels 2:9-22.

Yang, D., N. Shcheynikov, W. Zeng, E. Ohana, I. So, H. Ando, A. Mizutani, K. Mikoshiba, and S. Muallem. 2009. "IRBIT coordinates epithelial fluid and $\mathrm{HCO}^{-}$secretion by stimulating the transporters $\mathrm{pNBC} 1$ and CFTR in the murine pancreatic duct." J Clin Invest 119(1):193-202.

Yoshikawa, F., H. Iwasaki, T. Michikawa, T. Furuichi, and K. Mikoshiba. 1999a. "Cooperative formation of the ligand-binding site of the inositol 1,4, 5- trisphosphate receptor by two separable domains." J Biol Chem 274(1):328-34.

-. 1999b. "Trypsinized cerebellar inositol 1,4,5-trisphosphate receptor. Structural and functional coupling of cleaved ligand binding and channel domains." J Biol Chem. 274(1):316-27.

Yoshikawa, S., T. Tanimura, A. Miyawaki, M. Nakamura, M. Yuzaki, T. Furuichi, and K. Mikoshiba. 1992. "Molecular cloning and characterization of the inositol 1,4,5-trisphosphate receptor in Drosophila melanogaster." J Biol Chem 267(23):16613-9.

Zhang, S., C. Hisatsune, T. Matsu-Ura, and K. Mikoshiba. 2009. 
"G-protein-coupled receptor kinase-interacting proteins inhibit apoptosis by inositol 1,4,5-triphosphate receptor-mediated $\mathrm{Ca} 2+$ signal regulation." J Biol Chem 284(42):29158-69.

Zhang, S., S. Malmersjo, J. Li, H. Ando, O. Aizman, P. Uhlen, K. Mikoshiba, and A. Aperia. 2006. "Distinct role of the N-terminal tail of the Na,K-ATPase catalytic subunit as a signal transducer." J Biol Chem. 281(31):21954-62. 


\section{$\mathrm{IP}_{3}-\mathrm{IP}_{3}$ receptor and DAG-Protein Kinase C}

Extracellular signals

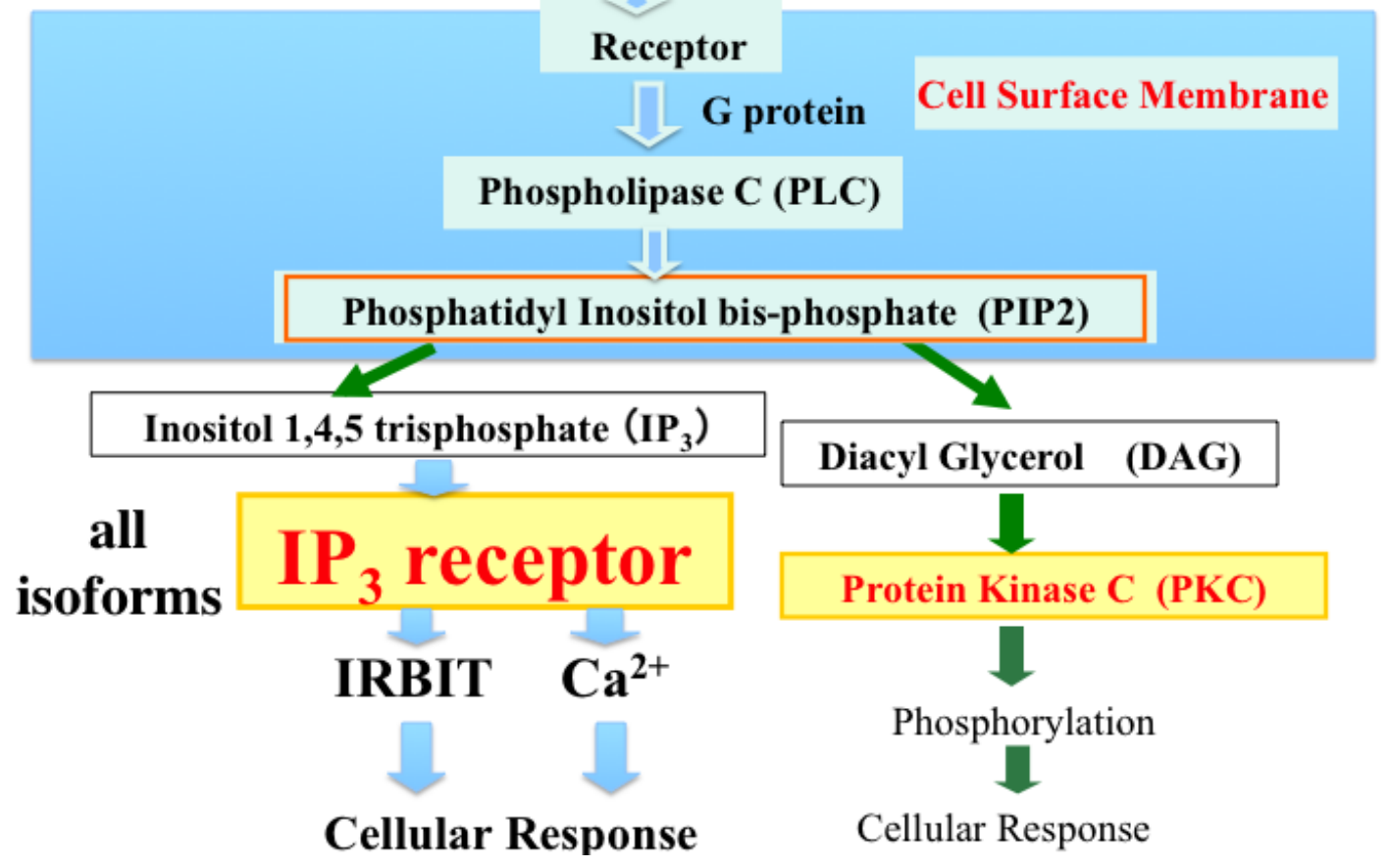

Figure 1 


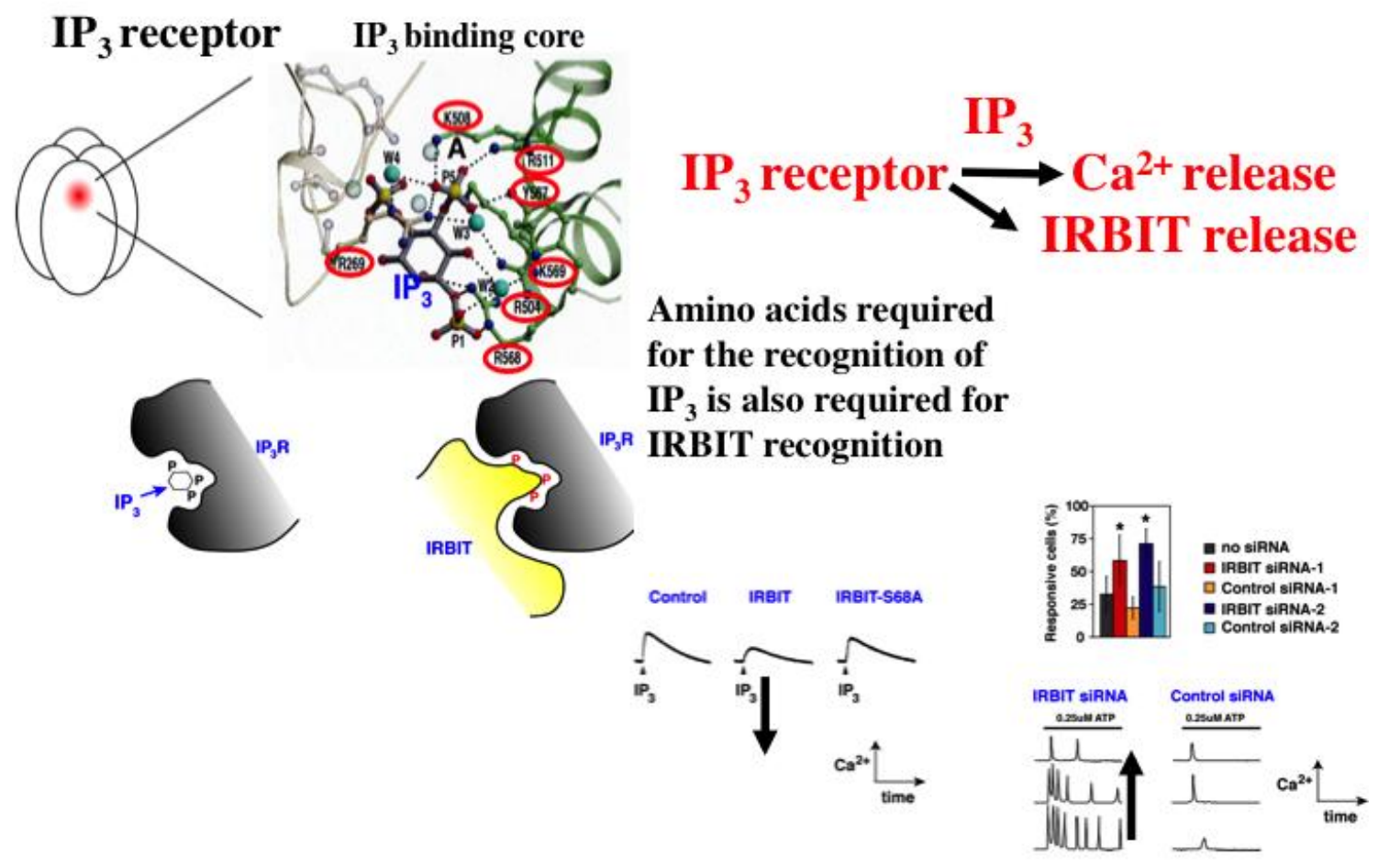

Figure 2 

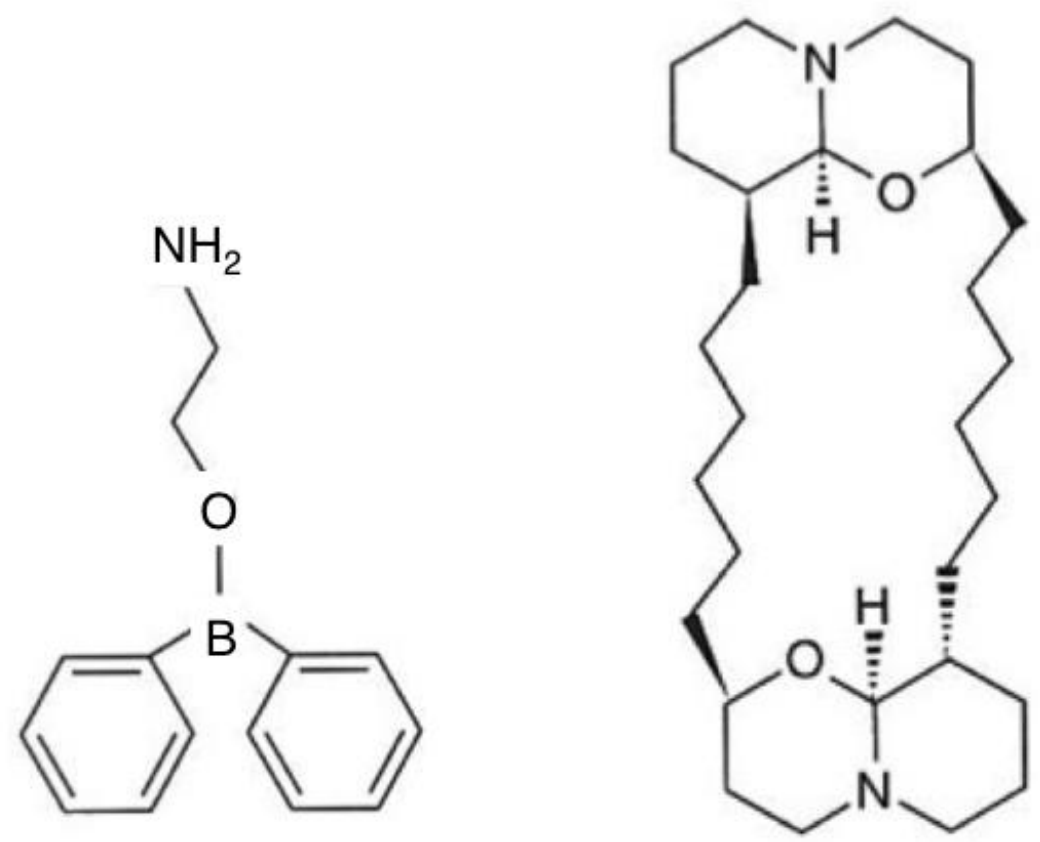

Figure 3 


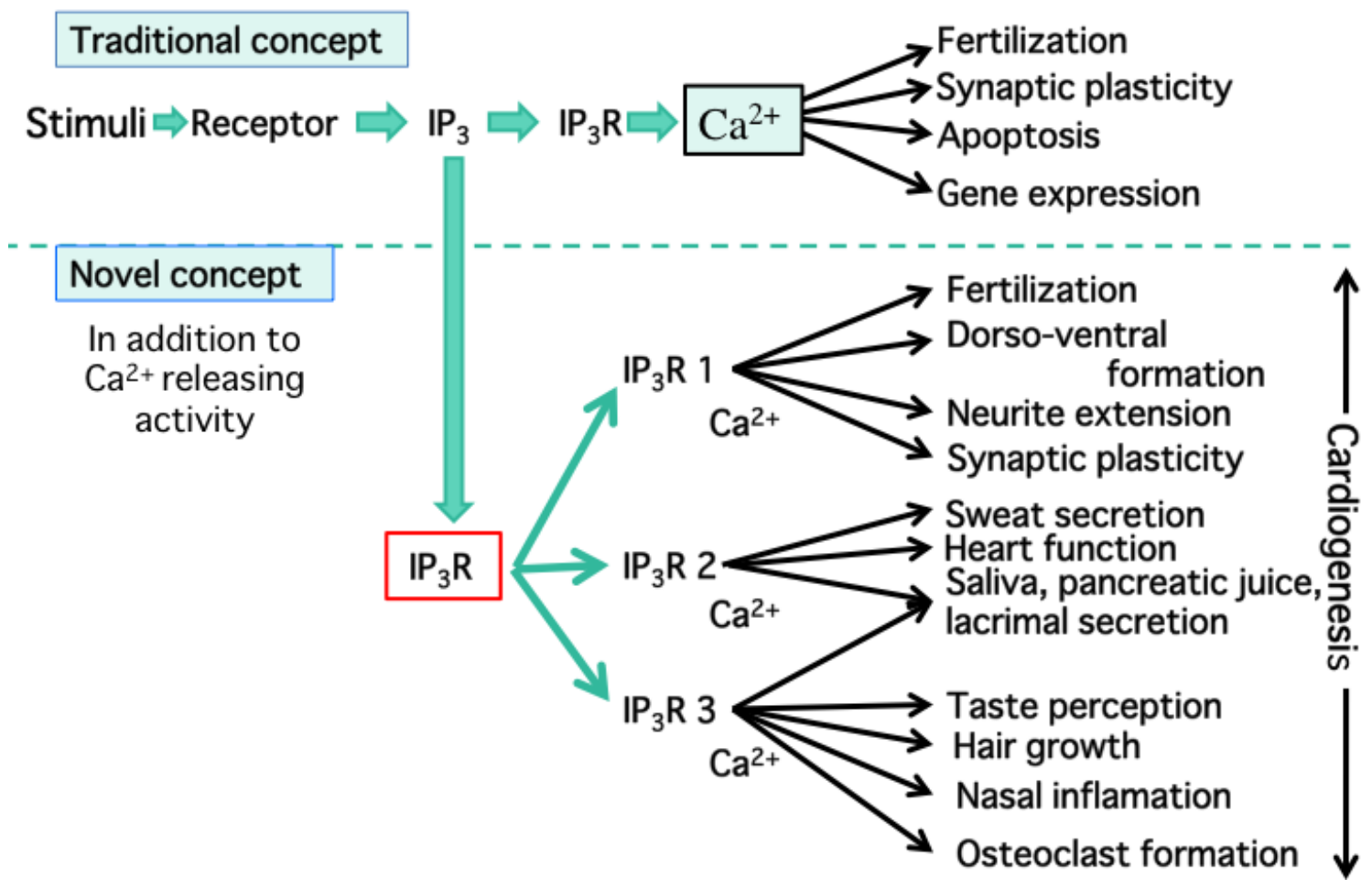

Figure 4 